\title{
Mechanical Strength Analysis of Bamboo for Flood Resilient Shelters: A Preliminary Study
}

\author{
Rina Yadav, Cheng-Chen Chen", Wen-Cheng Shao, Lih-Yau Song \\ College of Design, National Taipei University of Technology, 1, Sec. 3, Zhongxiao E. Rd., Taipei 10608 Taiwan
}

Received December 5, 2020; Revised February 17, 2021; Accepted March 23, 2021

\section{Cite This Paper in the following Citation Styles}

(a): [1] Rina Yadav, Cheng-Chen Chen, Wen-Cheng Shao, Lih-Yau Song "Mechanical Strength Analysis of Bamboo for Flood Resilient Shelters: A Preliminary Study," Civil Engineering and Architecture, Vol. 9, No. 2, pp. 420-426, 2021. DOI: 10.13189/cea.2021.090215.

(b): Rina Yadav, Cheng-Chen Chen, Wen-Cheng Shao, Lih-Yau Song (2021). Mechanical Strength Analysis of Bamboo for Flood Resilient Shelters: A Preliminary Study. Civil Engineering and Architecture, 9(2), 420-426. DOI: 10.13189/cea.2021.090215.

Copyright $\subseteq 2021$ by authors, all rights reserved. Authors agree that this article remains permanently open access under the terms of the Creative Commons Attribution License 4.0 International License

\begin{abstract}
The main objective of the study was to investigate the mechanical properties of Moso bamboo species (Phyllostachys pubescens) in wet and dry conditions and waste rubber engineered bamboo, according to climate for temporary shelter design during flood occurrence. For experiment, bamboo of diameter 5 $\mathrm{cm}$ and made four samples (length $25 \mathrm{~mm}$, width $3 \mathrm{~mm}$ and thickness $1.5 \mathrm{~mm}$ ) for testing tensile strength and flexure modulus (length $13 \mathrm{~mm}$, width $2 \mathrm{~mm}$ and thickness $1 \mathrm{~mm}$ ). The study finds that the tensile stress for dry sample (A) was $29.0 \mathrm{MPa}$; elongation break was $4.5 \%$ and these parameters for water soaked sample (A1) were $17.1 \mathrm{MPa}$ and $10.6 \%$ respectively. Tensile stress for dry sample laminated with rubber tube (B) was $31.5 \mathrm{MPa}$; elongation break was $3.1 \%$ and these parameters for rubber tube laminated water soaked sample (B1) were $19.9 \mathrm{MPa}$ and $5.6 \%$ respectively. Flexural strength for samples A, A1, B and B1 were 290.5, 283.1, 339.9 and $292.8 \mathrm{MPa}$ respectively. Results indicate that the strength of rubber tube laminated samples increases. The study concludes that vehicles' waste rubber tubes can be utilized to enhance the strength of bamboo for making temporary shelter in flood affected areas.
\end{abstract}

Keywords Bamboo, Mechanical Properties, Tensile Strength, Flexural Modulus, Temporary Shelter, Waste Rubber Tube

\section{Introduction}

Due to technological advancement, vehicle wheels' inner tube as a polymeric waste is growing rapidly every passing year which is causing environmental damage [1-3]. This waste material has impacted water, soil, atmosphere and $\mathrm{CO}_{2}$ emissions. Above all this also has a huge effect on human and animal's health system [4]. Inner tubes are made of non-biodegradable synthetic materials, a type of butyl rubber. Staffordshire based researcher disclose that every year 152,500,000 inner tubes are disposed of landfill [5].

Materials play a major role in making houses durable and comfortable. Two types of parameters are required in construction building materials, physical or structural such as, sand, cement, bricks, wood, plastic etc. and functional such as comfort, shape and durability [6]. Various kinds of building materials are used in construction such as steel, wood, concrete, and masonry. Each material has its own properties like strength, durability, weight which makes it suitable for a particular use. There are mainly two types of construction materials are available: natural material such as stone and wood; and man-made material such as concrete and steel [7]. For environmental point of view, carbon emission from building industry contributes around $80 \%$ of emissions from industrial processing [8-10]. Every year millions of new buildings are being constructed and new non-ecofriendly construction materials are being introduced; however, the materials used in ancient time were ecofriendly [11-13]. Traditional 
material and methods were comfortable for both cold and hot environmental conditions due to conservation of energy. The construction work from mud houses to contemporary infrastructure in India depends on a variety of locally available materials [14-16]. Major construction material source falls under the category of wood from plants and fibrous crops which is a generic building material and is used in building a lot in many form of construction in different climates [17].

Bamboo is a type of wood which is utilized in temporary houses. Bamboo is fundamentally a giant grass that comes from sub family bambusoideae and family Poaceae or Gramineae. Sub family bambusoideae comprises both woody and herbaceous bamboos with more than 1,500 species altogether [18]. Recently, engineered structural bamboo products (SBPs) have got more attention; however, due to limited material property data and proper building code it provides huge space to explore. Dixon et al. have performed structural, thermal, and moisture on processing of SBPs for Moso bamboo [19]. Bamboo has a wider life span than other wood products; it can be curved without breaking [20]. The bamboo as construction material should follow preservation process because it is susceptible to termites and fungal attack [21]. Bamboo's fibers with high mechanical strength can be a sustainable alternative to synthetic fibers for application in construction work [22-25]. From eco-friendly point of view bamboo work as a valued sink for carbon absorption, it absorbs about 17 tons of carbon per year per hectare of area. India had make plan of an additional carbon sink of 2.5-3.0 Gigatonnes of carbon dioxide by the year 2030 [26].

The mechanical properties consist of strength, modulus (stiffness), and Poisson's ratio etc. The strength is evaluated to test bearing capabilities of building materials. The modulus property defines the ability to resist deformation [27]. Testing is required for evaluation of selected material for safety, risk involved in and durability of constructed structure. It helps in saving expensive repair and reduces the loss of lives and properties [28]. Various different physical properties are involved in material testing [29]. Harries et al. have used "dogbone" style standard test method to determine the tension capacity of bamboo parallel to the fibers [30]. Sharma et al. have used engineered Phyllostachys pubescens (Moso) bamboo in the form of laminated and scrimber bamboo and have compared with grain bamboo. Studies of mechanical propertis have shown that laminated bamboo has increased strength in properties in comparison to grain [31]. Amir Mofidi et al. have used engineered bamboo samples and experimentally investigated the properties of new composite structures of bamboo culms formed with different bio-based and synthetic matrices such as full culm bamboo composite (FCB)-epoxy matrix (EPX)-improved polyvinyl chloride (PVC) jacket specimen. Strength, ductility, stiffness and absorbed energy were found advantageous when compared to the control column of a non-composite bamboo bundle [32].

S. Karthick et al. have concluded that the bamboo is suitable for non-load bearing and lightweight reinforced temporary structures [33]. Therefore, this paper proposed an original approach to evaluating the flexural strength and tensile strength of Moso bamboo for making temporary shelter in flood affected area. Authors have chosen Dhemaji area in Assam for making temporary shelter during flood situation, therefore bamboo is best suited locally available material for the construction of temporary shelter houses.

\section{Materials and Methods}

This part includes preparation of samples from bamboo and flexural modulus and strength testing.

\subsection{Sample Preparation}

Bamboo samples were collected from Linkou, Taoyuan region, Taiwan. The Moso bamboo (Figure 1) grew on a South-facing slope with an angle of $25^{\circ}$. For the experiment on bamboo - we took bamboo of diameter 5.0 $\mathrm{cm}$ and made four samples (Table 1). First sample (A) was dried one, second sample (A1) was water soaked for 25 days. Third sample (B) was made by covering with waste wheels' tubes over bamboo and then it was soaked bamboo in water for 25 days to make sample four (B1) (Figure 2).

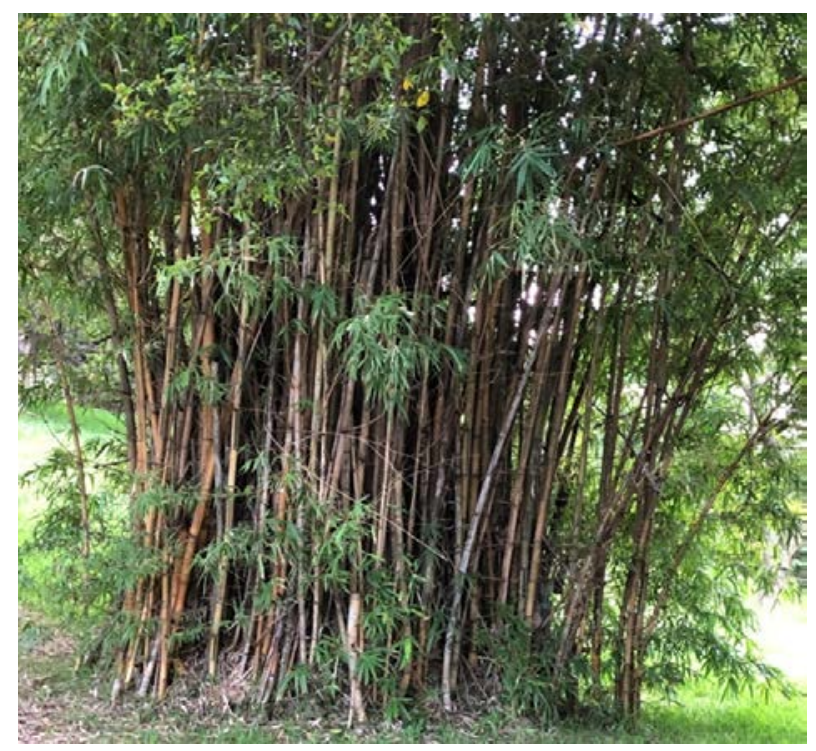

Figure 1. Bamboo tree

In order to prepare engineered bamboo samples, waste cycle tubes were collected from the cycle repairing shops to reach two purposes: first, to strengthen mechanical properties such as tensile strength and mechanical strength and second, to save the environment by using waste 
materials.

Samples were tested individually for their mechanical properties and compared for their flexural modulus and strength. Using rubber provides three main purposes: first it added the strength of bamboo and second, it protects bamboo from water and above all, it protects environment by reuse of rubber waste material.

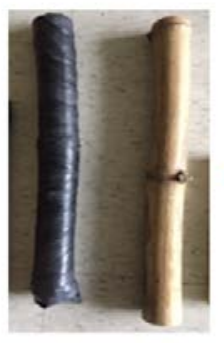

(a)

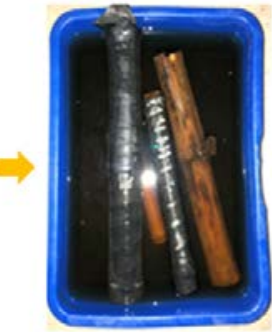

(b)

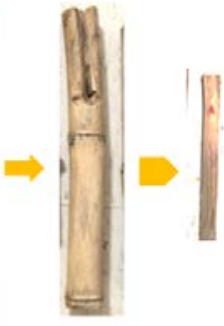

(c) properties of bamboo culms-Test methods" and ASTM D143-09 standard test methods respectively have been used $[34,35]$.

\subsubsection{Flexural modulus and strength}

Flexure test is a method to measure the mechanical properties of materials when it is subjected to bending load. Flexural modulus and strength are the force needed to bend a beam of material which measures resistance or stiffness of a material. It shows the material's flexibility before its permanent deformation. For testing a flat rectangular specimen is loaded at three points testing machine (Figure 3) and pulled until failure. ISO 22157:2019 standard procedure stipulates standard testing technique to define flexural modulus and strength [22].

\section{Procedure to test flexural modulus}

The flexural properties of the fabricated bamboo samples were measured using Gotech AI-3000 system (Figure 4) at a cross-head speed of $5 \mathrm{~mm} / \mathrm{min}$ (according to ISO 22157:2019). The reported values of flexural properties were averaged from at least three bamboo samples of the same type [29].

Table 1. Samples and their descriptions

\begin{tabular}{|c|c|}
\hline Sample code & Sample description \\
\hline A & Bamboo diameter $5.0 \mathrm{~cm}$ \\
\hline A1 & Bamboo $5.0 \mathrm{~cm}$ diameter soaked in water \\
\hline B & Bamboo laminated with rubber tube \\
\hline B1 & $\begin{array}{c}\text { Bamboo laminated with rubber tube and } \\
\text { soaked in water }\end{array}$ \\
\hline
\end{tabular}

\subsection{Material Testing}

These mechanical properties are evaluated through small scale material tests performed on standard-sized specimens [27] and standard test method. To measure flexural and tensile strength, "ISO 22157:2019, Bamboo structures-Determination of physical and mechanical

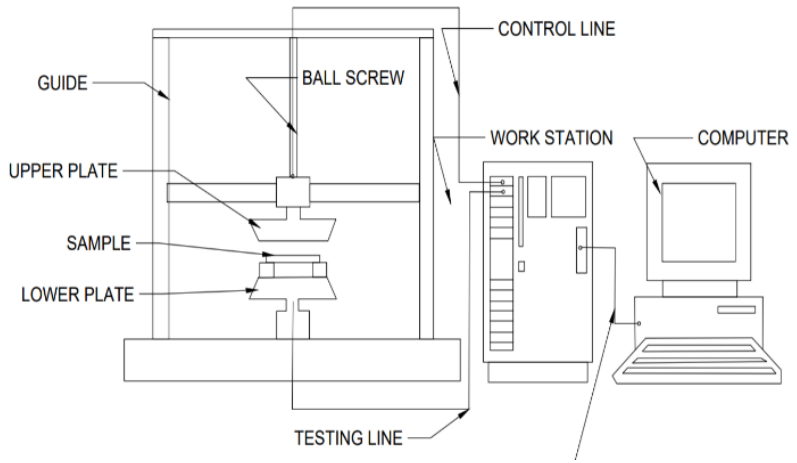

Figure 3. Flexure three point testing machine sketch
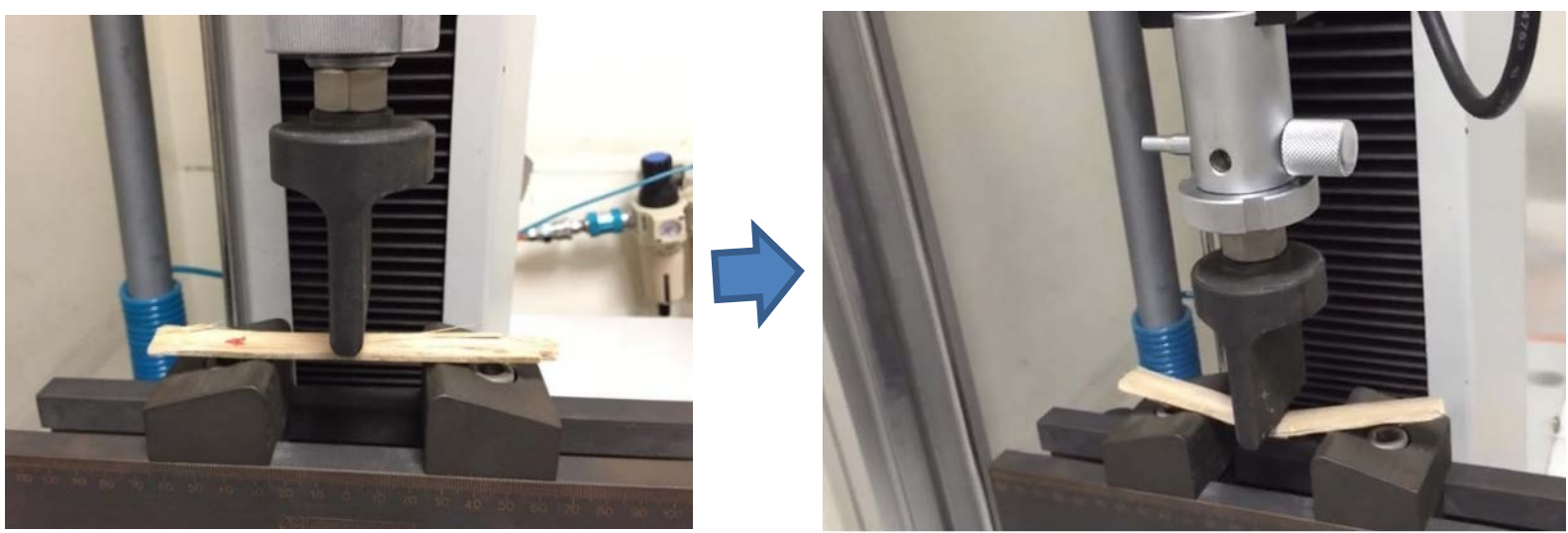

Figure 4. A digital photograph of flexural modulus and strength testing machine 


\subsubsection{Tensile Strength}

The tensile strength dispersal of fibers is a key mechanical property of bamboo [36]. Hence, understanding the effects in the tensile properties of this is important. In the present study, bamboo samples were tested with tension at several different engineered samples.

The tensile strength of the samples was measured with reference to the ASTM D143-09 standard test method (Figure 5) for small clear specimens of timber using a GOTECH, AI-7000s tensile-testing machine (Taichung, Taiwan) (Figure 6). Samples were cut from the $0.25 \mathrm{~m}$ sections of bamboo culms and were chosen from various radial locations along the sections.

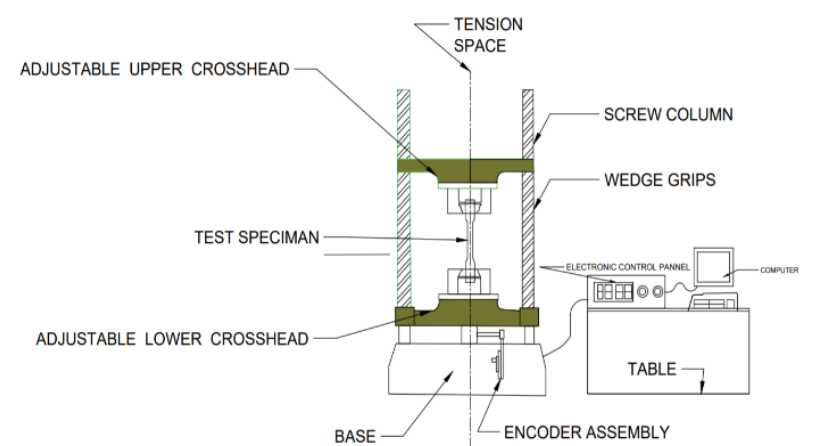

Figure 5. Tensile strength testing machine sketch

For the calculation, experiments were performed three times for the same samples from the internodes of $0.5 \mathrm{~m}$ subsections and the loading rate was set to $1 \mathrm{~mm} / \mathrm{min}$. All tests were carried out at room temperature. The tensile strength $\left(\sigma_{t}\right)$ was calculated by measuring the ultimate load at failure of the test $\left(F_{t}\right)$ and then it was divided by the cross section of the sample across the gauge length $\left(A_{t}\right)$. The following given formula was used to calculate the tensile strength [37].

$\sigma t=F t / A t$

\section{Tensile strength test procedure}

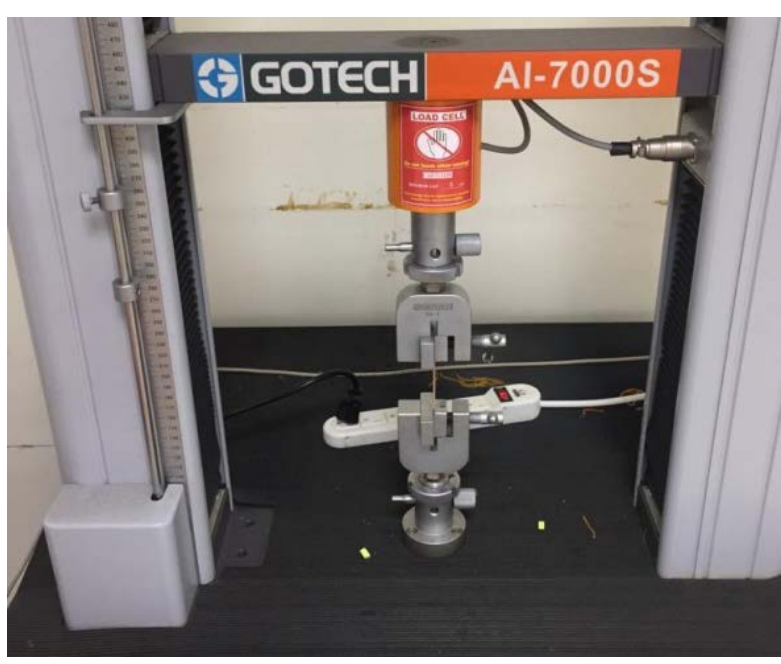

Figure 6. A digital photograph of Tensile strength testing machine
Bamboo sample was gripped by an apparatus at both ends, which stretches transversely until it breaks. The stretching force is called a load, which is plotted against material length change or displacement and load is transformed in to a stress value and displacement is converted to strain value $[38,39]$.

\subsection{Criteria for Testing the Sample Material}

The test parameters are as follows:

Test: Universal tensile test

UTM type: Machine

Load cell: Force500

Extensometer: XHead

Test area: lower test area

Tensile Strength dimension: $\left(1 \mathrm{~N} / \mathrm{mm}^{2}=1 \mathrm{MPa}\right)$

\subsection{Statistical Analysis}

The analyses were performed in triplicate. The results were analyzed using analysis of variance (ANOVA) and Duncan's test (IBM SPSS V. 20.0 software, SPSS, New York). Differences were calculated using Pearson's correlation to recognize the significant difference among the samples $(p \leq 0.05)$ [40].

\section{Results and Discussions}

\subsection{Flexural Properties: Flexural Modulus and Strength}

The modulus of elasticity in flexure was measured by obtaining the load-deformation curve in the flexural strength test. An Epsilon extensometer with a travel gauge of $25 \mathrm{~mm}$ was used to measure the mid-span deflection of the samples during the flexural strength test.

Table 2. Mechanical properties of selected samples

\begin{tabular}{|c|c|c|}
\hline Sample & $\begin{array}{c}\text { Flexural modulus } \\
(\mathrm{MPa})\end{array}$ & $\begin{array}{c}\text { Flexural strength } \\
(\mathrm{MPa})\end{array}$ \\
\hline A & $15401.9 \pm 120$ & $290.5 \pm 9$ \\
\hline A1 & $11728.8 \pm 103$ & $283.1 \pm 8$ \\
\hline B & $16561.9 \pm 110$ & $339.9 \pm 11$ \\
\hline B1 & $12476.7 \pm 109$ & $292.8 \pm 6$ \\
\hline
\end{tabular}

The measurement and calculation of the modulus of elasticity were carried out according to ISO 22157:2019 at room temperature. The mechanical properties of the prepared samples, including the flexural modulus (FM), and flexural strength (FS), were measured. (Table 2) The FM and FS of sample A and B were found to be 15401.9 and 290.5 MPa and 16561.9 and 339.9 MPa respectively. However, these values were 11728.8 and $283.1 \mathrm{MPa}$ and 12476.7 and 292.8 MPa in case of water soaked bamboo (sample A1 and B1). 


\subsection{Tensile Strength}

Table 3. Tensile strength of selected samples

\begin{tabular}{|c|c|c|}
\hline Sample & $\begin{array}{c}\text { Tensile stress } \\
\text { (MPa) }\end{array}$ & $\begin{array}{c}\text { Elongation at break } \\
\text { (\%) }\end{array}$ \\
\hline A & $29.0 \pm 0.8$ & $4.5 \pm 0.2$ \\
\hline A1 & $17.1 \pm 0.3$ & $10.6 \pm 0.6$ \\
\hline B & $31.5 \pm 0.9$ & $3.1 \pm 0.1$ \\
\hline B1 & $19.9 \pm 0.4$ & $5.6 \pm 0.4$ \\
\hline
\end{tabular}

The tensile strength of the samples was measured according to the ASTM D143-09 standard test method. Tensile strength of bamboo was $29.0 \mathrm{MPa}$. Bamboo undergoes brittle failure. i.e., it breaks sharply without plastic deformation. Bamboo which undergoes brittle failure gives a breaking elongation of $3.1 \%-10.6 \%$. Tensile stress directly breaks the dry sample of bamboo while in the case of water soaked bamboo sample stress decreases first from 10.6 to 9 MPa then slightly increases and then breaks above $9 \mathrm{MPa}$. (Figure 9) The study highlights that bamboo as structural elements can be utilized in constructions in different ways which are at variance with the present study.

The results of the tensile strength tests of the bamboo samples are provided in Table 3. The maximum tensile stress of samples was 31.5 MPa for sample B. For water dipped sample without rubber rapping (sample A1) tensile stress was found to be 17.1 MPa. Elongation break 11\% was highest in case of sample covered with rubber tube. Elongation break was $5.6 \%$ for sample B1 (Figure 7), $4.5 \%$ for sample A (Figure 10) and $3.1 \%$ for sample B. (Figure 8) Therefore, the tensile strength of the wet bamboo, which mainly comes from the tensile capacity of the cellulose fibers, is reduced than the tensile strength of dry bamboo. All the results presented as mean and standard deviation form $(n=3)$ [15].

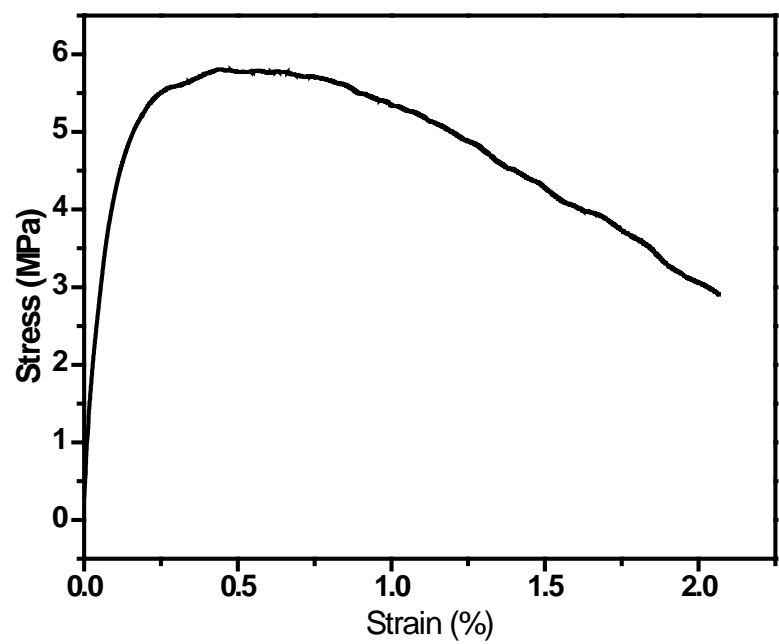

Figure 7. Stress and stain curve of sample B1 (ASTM D143-09 standard test method) [35]

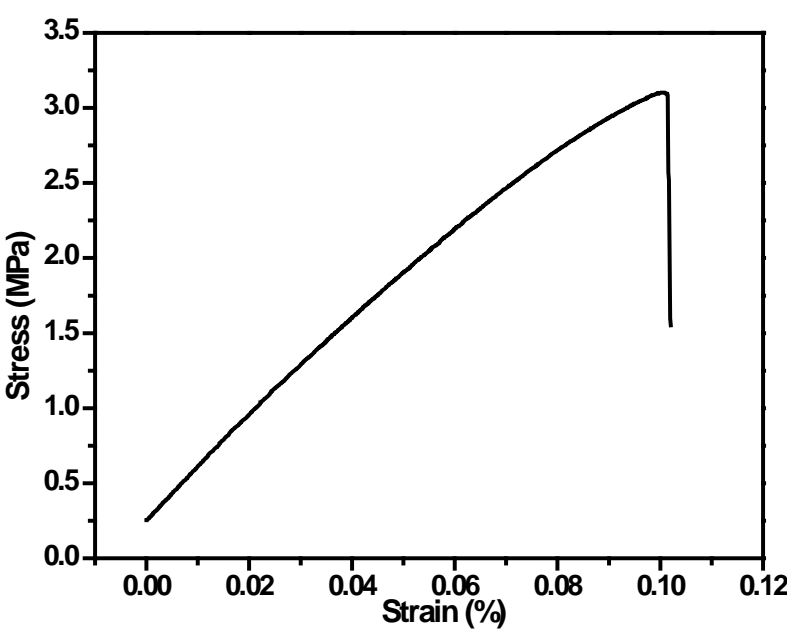

Figure 8. Stress and stain curve of sample B (ASTM D143-09 standard test method) [35]

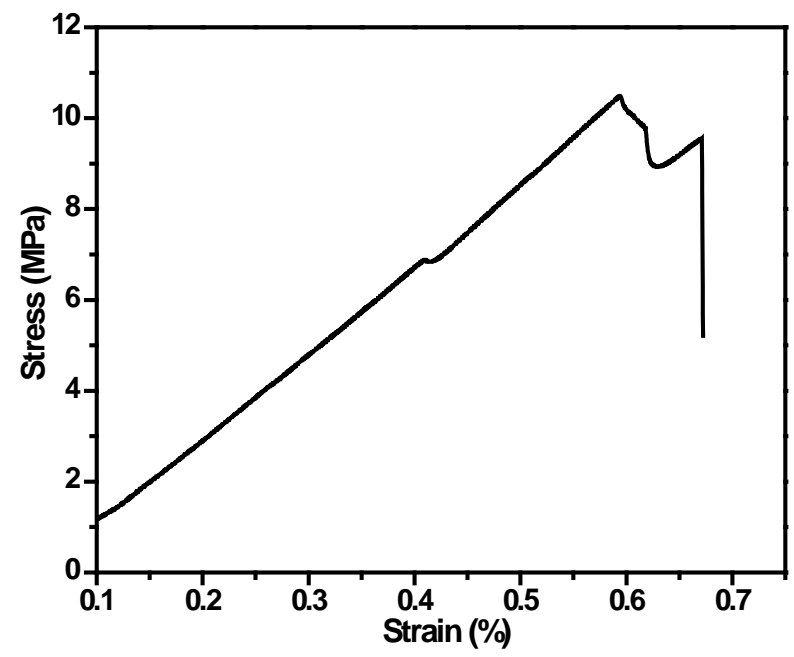

Figure 9. Stress and stain curve of sample A1 (ASTM D143-09 standard test method) [35]

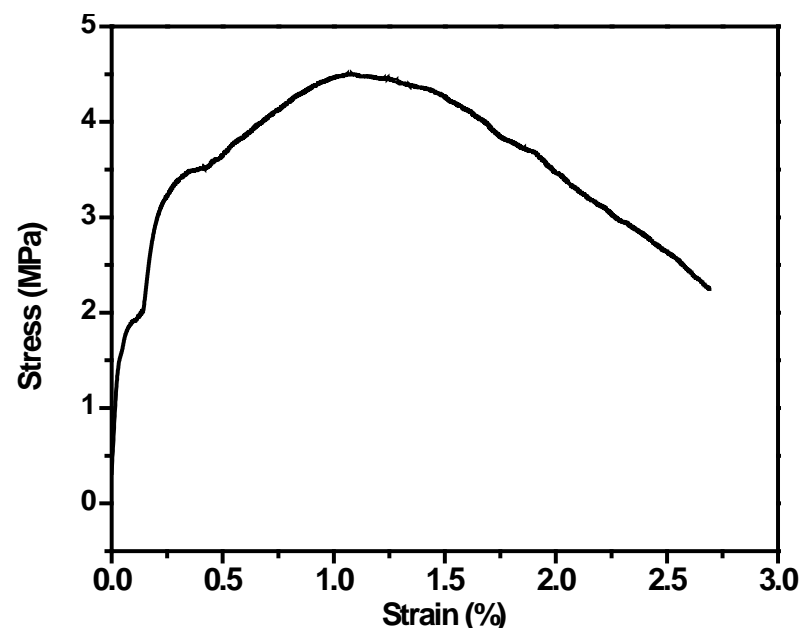

Figure 10. Stress and stain curve of sample A (ASTM D143-09 standard test method) [35] 


\section{Conclusions}

In order to use sustainable material for building temporary shelter in flood affected areas, Moso bamboo was used to test and compare mechanical properties of dry, water soaked and rubber tube laminated specimens. Waste rubber tube was used in order to recycle these materials and save the environment. Samples were tested and analyzed to examine their tensile and flexural Properties. The tensile strength and flexural strength of the water dipped bamboo were less than that of the dry samples and these properties of rubber tube laminated samples were greater than the without laminated samples, which indicates that laminated bamboo are better choice for making resilient temporary shelter in flood prone areas because rubber protect bamboo from water, and provides strength simultaneously. Therefore, bamboo is suitable for preparing temporary housing in the flood situation; however, further advanced experiments with other types of wood materials are required to ensure the reliability before application in the real scenario and authors may continue this study in the near future.

\section{Acknowledgments}

Authors are thankful to department of Design, National Taipei university of Technology, Taipei, Taiwan for providing the facilities. We also would like to acknowledge Dr. Kartik Behera for performing flexural modulus and strength test.

\section{Conflict of Interest}

Authors have no conflicts of interest.

\section{REFERENCES}

[1] Buss A.H., Kovaleski J.L., Pagani R.N., da Silva V.L., Silva J.M., "Proposal to reuse rubber waste from end-of-life tires using thermosetting resin,” Sustainability, 2019, 11, 6997. DOI: $10.3390 /$ su11246997.

[2] Sienkiewicz M., Janik H., Borzędowska-Labuda K., Kucińska-Lipka J., "Environmentally friendly polymer-rubber composites obtained from waste tyres: A review,” Journal of Cleaner Production, vol. 147, pp. 560 571, 2017. DOI: 10.10.16/j.jclepro.2017.01.121.

[3] Landi D., Gigli S., Germani M., Marconi M., "Investigating the feasibility of a reuse scenario for textile fibres recovered from end-of-life tyres," Waste Management, vol. 75, pp. 187-204, 2018. DOI: 10.1016/j.wasman.2018.02.018.

[4] Piotrowska K., Kruszelnicka W., Bałdowska-Witos P., Kasner R., Rudnicki J., Tomporowski A., Flizikowski J., Opielak M., "Assessment of the Environmental Impact of a Car Tire throughout Its Lifecycle Using the LCA Method,”
Materials, vol. $12 \quad$ (24), 4177, 2019. DOI: 10.3390/ma12244177.

[5] Can you recycle bike tyres and inner tubes? Available online: https://resource.co/article/can-you-recycle-bike-tyres-and-in ner-tubes (accessed on 11/28/2020).

[6] Jamal H., "Role of materials in construction functional requirements of buildings,” Material Engineering, Jan 22, 2017.

(https://www.aboutcivil.org/role-of-materials-in-constructio n.html).

[7] Structural engineering basics. Available online: https://structuralengineeringbasics.com/what-types-of-const ruction-building-materials/ (accessed on 25/03/2020).

[8] Onat N.C., Kucukvar M., "Carbon footprint of construction industry: A global review and supply chain analysis," Renewable and Sustainable Energy Reviews, Volume 124, ID 109783, 2020. DOI: 10.1016/j.rser.2020.109783.

[9] Hoffert MI, Caldeira K, Benford G, Criswell DR, Green C, Herzog H, Jain AK, Kheshgi HS, Lackner KS, Lewis JS, Lightfoot HD, Manheimer W, Mankins JC, Mauel ME, Perkins LJ, Schlesinger ME, Volk T, Wigley TM., "Advanced technology paths to global climate stability: energy for a greenhouse planet,” Science, Vol. 298(5595), pp. 981-987, 2002. DOI: 10.1126/science.1072357.

[10] Peng C., Wu X., "Case study of carbon emissions from a building's life cycle based on bim and ecotect," Advances in Materials Science and Engineering, vol. 2015, Article ID 954651, 15 pages, 2015. DOI: 10.1155/2015/954651.

[11] Meggers, F.; Leibundgnt, H.; Kennedy, S.; Qin, M.; Schlaich, M.; Sobek, W.; Shukuya, M. Reduce $\mathrm{CO}_{2}$ from buildings with technology to zero emissions, Sustainable Cities and Society. 2012, 29-36.

[12] Anejo A.J., "Impact of concrete, steel and timber on the environment: A Review," International Journal of Technology enhancement and emerging engineering research, vol. 2(7), pp. 58-63, 2014.(http://paper.researchbi b.com/view/paper/54821).

[13] Alireza J., Smith I.F.C., Saeidi N., Hebel D.E., “Mechanical Properties of Bamboo through Measurement of Culm Physical Properties for Composite Fabrication of Structural Concrete Reinforcement,” Frontiers in Materials, vol. 6, pp. 15, 2019. DOI: 10.3389/fmats.2019.00015.

[14] 7 Most commonly used construction and building materials in

India. Available online: https://gosmartbricks.com/construct ion-and-building-materials-in-india/ (accessed on 25/03/202 $0)$.

[15] Fitriana L., Tsai M.T., "Safety assessment of moso bamboo column under fire by using bamboo as protection layer," 8th International Conference on Architecture Research and Design

(AR+DC) November 1-2, 2016. (https://www.neliti.com/pu blications/173160/safety-assessment-of-moso-bamboo-colu mn-under-fire-by-using-bamboo-as-protection\#cite).

[16] Mahdavi-Harsini, M.; Clouston P., Arwade S.R., "Development of laminated bamboo lumber: review of processing, performance, and economical considerations," Journal of Material in Civil Engineering, vol. 23 (7), pp. 1036-1042, 2011. DOI: 10.1061/(ASCE)MT.1943-5533.00 
00253.

[17] Different building materials used in construction works. Available online: https://medium.com/construction-tips-tric ks/different-building-materials-used-in-construction-works60c1cbffc478 (accessed on 26/03/2020).

[18] Nurdiah E.A., "The potential of bamboo as building material in organic shaped buildings," Procedia-Social and Behavioral Sciences, Vol. 216, pp. 30-38, 2016. DOI: 10.1016/j.sbspro.2015.12.004.

[19] Dixon P.G., Gibson L.J., "The structure and mechanics of moso bamboo material," Journal of the Royal Society Interface, vol. 11, ID 20140321, 2014. DOI:10.1098/rsif.20 14.0321.

[20] Anagal V., Darvekar G., Gokhale V.A., Bamboo construction: learning through experience. Architecture-Space \& People, pp. 36-43, 2010.

[21] Cruz C.A., "Wright's organic architecture: from follows function to form and function are one," Wolkenkuckucksheim,

32, 2012. Vol. 17.(https://www.cloud-cuckoo.net/journal19 96-2013/inhalt/de/heft/ausgaben/112/Beitraege/2.2\%20\%20 \%20Cruz.pdf).

[22] Manandhar R., Kim J.H., Kim J.T., "Environmental, social and economic sustainability of bamboo and bamboo-based construction materials in buildings," Journal of Asian Architecture and Building Engineering, vol. 18:2, pp. 49-59, 2019. DOI: 10.1080/13467581.2019.1595629.

[23] Huang D., Zhou A., Bian, Y., "Experimental and analytical study on the nonlinear bending of parallel strand bamboo beams," Construction Building Material, vol. 44, pp. 585-592, 2013, 585-592.10.1016/j.conbuildmat.2013.03.05 0.

[24] Fang C., Jiang Z., Sun Z., Liu H., Zhang X., Zhang R., Fei B., "An overview on bamboo culm flattening," Construction and Building Material, vol. 171, 65-74, 2018. DOI: 10.1016/j.conbuildmat.2018.03.085.

[25] Li R., Cao P., Zhang S., Xu W., Ekevad M., Guo X., "Prediction of cutting force during gypsum fiber composite milling process using response surface methodology,” Wood Fiber Science, vol. 49 (4), pp. 453-460, 2017. (http://www.diva-portal.org/smash/record.jsf?pid=diva2\%3 A1150151\&dswid=-1042)

[26] Grow bamboo, capture carbon. Available online: https://indiaclimatedialogue.net/2019/01/21/growing-bamb oo-forests-could-boost-carbon-capture-in-india/ (accessed on $04 / 05 / 2020$ ).

[27] Naser M.Z., "Properties and Material Models for Common Construction Materials at Elevated Temperatures," Construction and Building Materials. Vol. 215, pp. 192-206, 2019. DOI: 10.1016/j.conbuildmat.2019.04.182.

[28] The Importance of Construction Materials Testing. Available online: https://atcgroupservices.com/the_importa nce_of_construction_materials_testing/ (accessed on 04/05/2020).

[29] Baldaniya B.H., George E., Patel S.B., “Test of bamboo material for structural purpose," Paripex Indian Journal of Research, vol. 2 (4), 2013. DOI: 10.36106/PARIPEX.

[30] Harries K.A., Sharma B., Richard M.J., "Structural use of full culm bamboo: The path to standardization," International Journal of Architectural Engineering and Construction, vol. 1, pp. 66-75, 2012. DOI: 10.7492/IJAEC.2012.008

[31] Sharma B., Gatóo A., Bock M., Ramage M., “Engineered bamboo for structural applications," Construction Building Material, vol. 81, pp. 66-73, 2015. DOI:10.1016/j.conbuild mat.2015.01.077

[32] Mofidi A., Abila J., Ng J.T.M., "Novel Advanced Composite Bamboo Structural Members with Bio-Based and Synthetic Matrices for Sustainable Construction," Sustainability, MDPI, Open Access Journal, vol. 12(6), pages 1-1, 2020.

[33] Karthik S., Rao P.R.M., Awoyera P.O., "Strength properties of bamboo and steel reinforced concrete containing manufactured sand and mineral admixtures,” Journal of King Saud University - Engineering Sciences, Volume 29, Issue 4, pp. 400-406, 2017. DOI: 10.1016/j.jksues.2016.12. 003.

[34] ISO 22157:2019, Bamboo structures-Determination of physical and mechanical properties of bamboo culms-Test methods. Available online: https://www.iso.org/standard/65 950.html (accessed on 02/06/2021).

[35] Astm D143-09 Standard Test Methods For Small Clear Especiments Of Timber, April 20, 2017. Available online https://www.scribd.com/document/345785530/ASTM-D14 3-09-STANDARD-TEST-METHODS-FOR-SMALL-CLE AR-ESPECIMENTS-OF-TIMBER-pdf (accessed on 02/06/2021).

[36] Shao J., Wang F., Li L., Zhang J., "Scaling Analysis of the Tensile Strength of Bamboo Fibers Using Weibull Statistics," Advances in Material Science and Engineering, vol. 2013, ID 167823, 2013. DOI: 10.1155/2013/167823.

[37] Plastic Properties and Testing. Available online: https://www.sciencedirect.com/topics/materials-science/fle xural-testing (accessed on 04/05/2020).

[38] Tension Testing. Available online: https://www.admet.com/ te sting-applications/test-types/tension-testing/ (accessed on 04/05/2020)

[39] Tensile Test Experiment. Available online: https://www.mt u. edu/materials/k12/experiments/tensile/ (accessed on 24/0 $5 / 2020)$.

[40] Biswal A.K., Lenka C., Panda P.K., Yang J.M., Misra P.K., "Investigation of the functional and thermal properties of Mahua deoiled cake flour and its protein isolate for prospective food applications,” LWT, Vol. 137, ID 110459, 2021, DOI:10.1016/j.lwt.2020.110459. 